\title{
Characterization of the Effect of Programmed Aeration on Energy Efficiency of Microalgae Cultivation System
}

\author{
Robert Bocsi*, Dora Rippel-Petho, Geza Horvath, Laszlo Hanak, Zoltan Hodai \\ Institute of Chemical and Process Engineering, Department of Chemical Engineering Science, University of Pannonia, Veszprem, \\ Hungary \\ Email: *bocsirobert@almos.uni-pannon.hu
}

How to cite this paper: Bocsi, R., RippelPetho, D., Horvath, G., Hanak, L. and Hodai, Z. (2017) Characterization of the Effect of Programmed Aeration on Energy Efficiency of Microalgae Cultivation System. World Journal of Engineering and Technology, 5, 481-486.

https://doi.org/10.4236/wjet.2017.53041

Received: April 27, 2017

Accepted: August 8, 2017

Published: August 11, 2017

Copyright $\odot 2017$ by authors and Scientific Research Publishing Inc. This work is licensed under the Creative Commons Attribution International License (CC BY 4.0).

http://creativecommons.org/licenses/by/4.0/

\begin{abstract}
With autotrophic microalgae cultivation, we can feed back the $\mathrm{CO}_{2}$ content of process streams and we can get lots of valuable organic compounds, among others biofuel components. For the production of energy source, we must reckon with the energy balance of the whole process. Densification and processing of microalgae can consume $50 \%-70 \%$ of the energy that can be extracted from the cells, therefore the cultivation should use such a little energy as it possible. In closed cultivation systems, there are three main energy intensive steps: artificial illumination, dissolution of gas compounds and mixing. We have carried out our measurements in our lab-scale screening photobioreactor system for the investigation of the most energy effective program for aeration. We have found the aeration program considerable solution for lower energy consumption in algae cultivation.
\end{abstract}

\section{Keywords}

Energy efficiency, Microalgae, Cultivation, Aeration

\section{Introduction}

In 2014 the total biomass production of the World was near 71 Mtoe ( 2.96 EJ). $50 \%$ of its total production was biodiesel. According to the BP World energy review, the production was $7.4 \%$ higher than in previous year. This can be a working force to research algae to energy systems [1].

When operating an algae cultivation system we should take care of energy balance also. Considering the product specification we should keep energy consumption at the level as low as it possible. So it is important to keep the low energy consumption as a design objective at the beginning. 
In an operating cultivation system, we should take care of the following needs of algae cells: sufficient flux of light in photosynthetically active radiation $(P A R)$ spectra, carbon source, mixing, and temperature management.

Though sunlight can be used for cultivation, the length of daily light cycles cannot be influenced. Artificial light sources can be used also, if the spectra of emitted light is in the $P A R$ region but we should calculate on additional energy consumption. The energy efficiency of the light source depends not only on heat conversion but there is a strong relationship of the ratio of $P A R$ photon flux and total photon flux.

Ageing process can be also observed at artificial light sources that lead to lower photon flux and lower efficiency [2] [3].

There are two main reasons for algae suspension mixing. The first reason is the intensification of dissolving $\mathrm{CO}_{2}$ in suspension. The second reason is to keep floating all algae cell to avoid sedimentation that leads to bad light distribution in the reactor. Near constant light flux the optical density increases by the increasing biomass concentration. In this case the lowering available photon flux at the deeper layer in algae suspension leads to light limitation. Proper gas distribution system necessarily solves the mixing problem, however there might be necessary to use mechanical mixing especially in open pond. Direct sunlight can be used as light source but without system cooling the suspension will be heated to $40^{\circ} \mathrm{C}$ or higher that is over the optimal range $\left(20^{\circ} \mathrm{C}-35^{\circ} \mathrm{C}\right)$ [4] [5] [6].

In photoautotrophic cultivation process $\mathrm{CO}_{2}$ is in dissolved or hydrogen carbonate form that depends on $\mathrm{pH}$. Obvious solution that we use that kind of carbon source is accessible on site. This source can be flue gas (average composition see in Table 1), natural gas or biogas. In this case, additional energy consumption can be occurred when the pressure of the input source is too low to be dispersed thru gas distribution system. When undesirable components (dust, $\mathrm{SO}_{\mathrm{X}}$, $\mathrm{H}_{2} \mathrm{~S}$ ) are present then we should take care of partial or total separation before feed into the reactors [7] [8].

\section{Materials and Methods}

We have set up the gas distribution system for our previously installed lab-scale PBR medium test system. $\mathrm{CO}_{2}$ input was mixed with filtered air and distributed

Table 1. Average flue gas composition.

\begin{tabular}{cc}
\hline Compound & Concentration \\
\hline $\mathrm{N}_{2}$ & $70-75(\mathrm{~V} / \mathrm{V}) \%$ \\
$\mathrm{CO}_{2}$ & $5-25(\mathrm{~V} / \mathrm{V}) \%$ \\
$\mathrm{H}_{2} \mathrm{O}$ & $9-14(\mathrm{~V} / \mathrm{V}) \%$ \\
$\mathrm{O}_{2}$ & $0.7-10(\mathrm{~V} / \mathrm{V}) \%$ \\
$\mathrm{SO}_{2}$ & $0-1500 \mathrm{ppm}$ \\
$\mathrm{CO}$ & $50-150 \mathrm{ppm}$ \\
Dust & $100-800 \mathrm{ppm}$ \\
Heavy metals & $0.05-0.5 \mathrm{ppm}$
\end{tabular}


by the following program.

\subsection{Lab Scale PBR System and Gas Distribution System}

The wall of the cylindrical reactors made of PET. The system contains membrane blower, $\mathrm{T} 2.5 \mathrm{CO}_{2}$ gas cylinder, and static gas mixer. Each $1 \mathrm{dm}^{3}$ reactor have individual immersed gas dispenser for uniform gas supplement with solenoid valve for input and non-return valve for the gas output (see Figure 1).

For the execution of gas dispensing program we have used $A D A M-5000 / T C P$ (Advantech) Ethernet-based distributed DA \& C system with ADAM-5069 8channel relay module extension. The gas distribution program was adapted to ADAMVIEW Data Acquisition software environment.

\subsection{Gas Supply, Dosing Program}

Photoautotrophic creatures use $\mathrm{CO}_{2}$ and light for photosynthetic activity in light

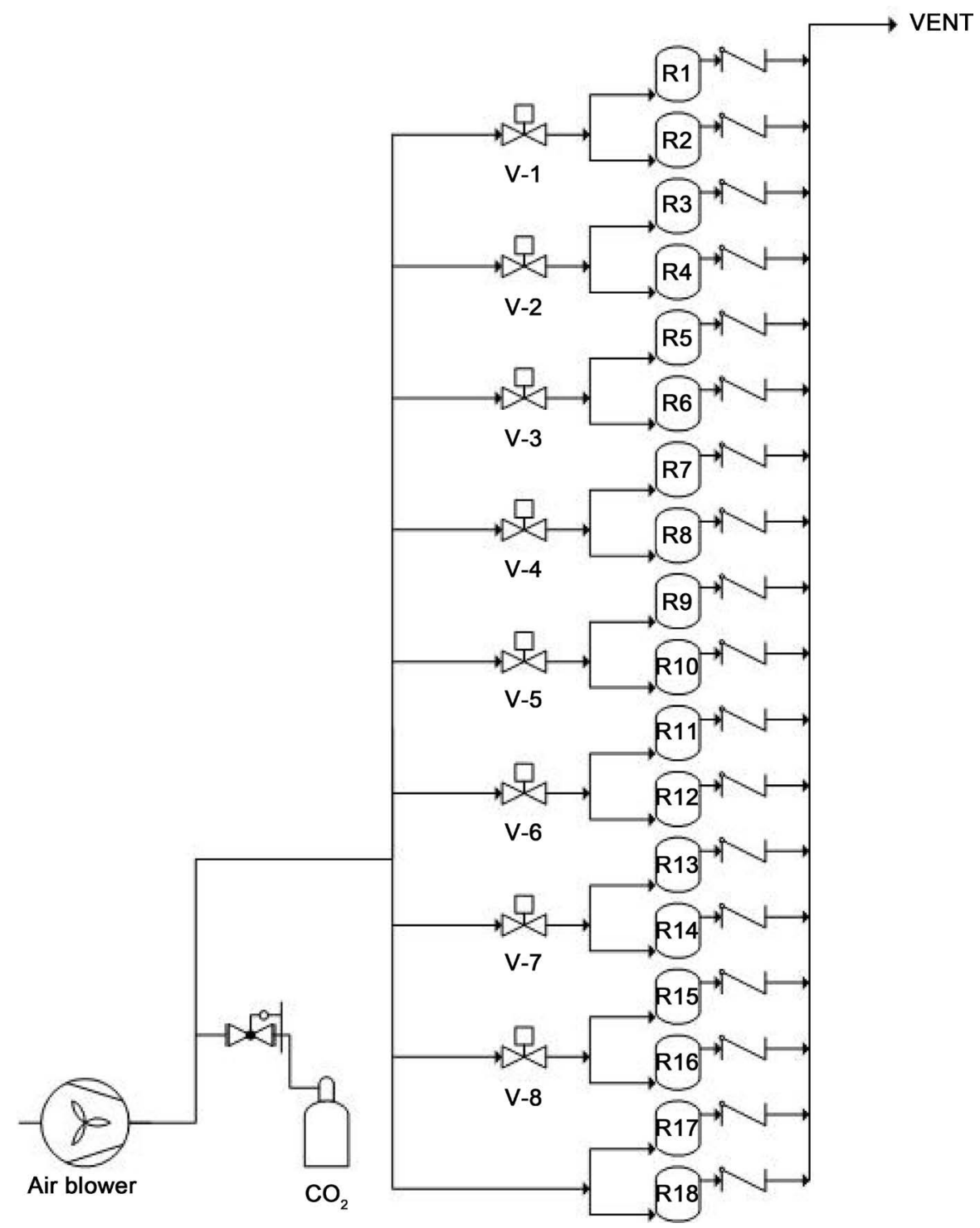

Figure 1. Schematic drawing of the gas dispensing system. 
Table 2. Gas dispensing program and relative energy consumption.

\begin{tabular}{cccc}
\hline \multirow{2}{*}{$\begin{array}{c}\text { Program } \\
\text { mode }\end{array}$} & Reactors & Length of the on/off cycle & $\begin{array}{c}\text { Power consumption } \\
\text { compared to reference }\end{array}$ \\
\cline { 3 - 4 } & & Continous $^{\mathrm{a}}$ & $100 \%$ \\
Ref. & R17, R18 & 30 minutes & $50 \%$ \\
$30 \mathrm{~m}$ & R1, R2, R3, R4 & 120 minutes & $50 \%$ \\
2H & R5, R6, R7, R8 & 240 minutes $^{\mathrm{C}}$ & $50 \%$ \\
$4 \mathrm{H}$ & $\mathrm{R} 9, \mathrm{R} 10, \mathrm{R} 11, \mathrm{R} 12$ & 1080 minutes $^{\mathrm{b}}$ & $66.6 \%$ \\
$\mathrm{D}$ & $\mathrm{R} 13, \mathrm{R} 14$ & 480 minutes $^{\mathrm{c}}$ & $33.3 \%$ \\
$\mathrm{~N}$ & $\mathrm{R} 15, \mathrm{R} 16$ &
\end{tabular}

a. Reference mode, continous aeration; $b$. The time shift of mode was in light mode; $c$. The time shift of mode was in dark mode.

phase. In dark phase there is no light for the photosynthetic activity, so algae use no $\mathrm{CO}_{2}$.

The gas feed stream contains $8(\mathrm{~V} / \mathrm{V}) \% \mathrm{CO}_{2}$ mixed in air with $540 \mathrm{dm}^{3} / \mathrm{h}$ total gas flowrate.

We have designed the program that each pairs of solenoid working with the same time cycle but they are in opposite (on/off) status. So the number of opened or closed valves was the same in every minute. This was good for minimizing the of pressure fluctuation in gas distribution system. The $\mathrm{D}$ and $\mathrm{N}$ mode were the opposites.

The length of dosing time was between 30 minutes and 16 hours. Accordingly the power consumption of the gas distribution system for the reactors was between $33 \%$ and $66 \%$ compared to reference (see in Table 2).

\subsection{Other Operating Parameters}

We used Sylvania Aquastar T8 fluorescent tube for the artificial lighting in 16/8 light dark cycles. This type of fluorescent tubes are intended to be used for promote the growth of aquatic plants, because they have high emission maximum in red and blue light spectrum.

We have used PQS-1 PAR Quantum sensor paired with Logbox SD data logger (Kipp \& Zonen) for the quantification of the irradiation. According the logged radiation data we have ascertained that there was no significant difference between the intensity of irradiation in light cycles.

For cultivation batch we have used enrichedBG-11 culturing medium with 80 $\mathrm{mg} / \mathrm{dm}^{3}$ nitrate content. BG-11 medium is commonly used for blue-green algae cultivation. The modification was made for promote biomass production.

The temperature of suspensions was $17^{\circ} \mathrm{C} \pm 1^{\circ} \mathrm{C}$.

The duration time of each test was 7 days.

For the quantification of biomass concentration we have used the optical density at the wavelength of maximum absorption of Chlorophyll (OD 681). The biomass concentration-OD681 function has been determined by its calibration curve. It was measured by filtration using Whattman GF/C filter and dry weight 
measurement at $90^{\circ} \mathrm{C}\left(\mathrm{R}^{2}=0.999\right)$.

\section{Results and Discussion}

All cultivation tests were carried out in minimum two parallel reactors and it has been repeated twice. Table 3 contains the biomass production that occurred in each mode. Calculations made from the relevant measurement data and contained results where the maximum deviation was $5 \%$.

The results can be aligned in 3 groups regarding to relative biomass production.

The first group contains $30 \mathrm{~m}$ and $D$ where relative biomass production is $90 \%$. These settings are the nearest to continuous gas supplement mode.

The second group contains $4 H$ and $2 H$ mode where the relative biomass production is $\sim 80 \%$. In these modes there are such long time periods where partial sedimentation can start.

The third group is the dark aeration mode. Here we can reach only $\sim 73 \%$ relative biomass production but in this case we use only $33 \%$ of reference energy consumption (Figure 2).

Table 3. Biomass production using gas dispenser program.

\begin{tabular}{ccc}
\hline \multirow{2}{*}{ Program } & \multicolumn{2}{c}{ Biomass production } \\
\cline { 2 - 3 } & Biomass $(\mathrm{mg})$ & Relative production (\%) \\
\hline Ref. & $440^{\mathrm{a}}$ & $100 \%$ \\
$\mathrm{n} \mathrm{m}$ & 397 & $90.2 \%$ \\
$4 \mathrm{H}$ & 369 & $83.9 \%$ \\
$\mathrm{D}$ & 360 & $81.8 \%$ \\
$\mathrm{~N}$ & 395 & $89.8 \%$ \\
\hline
\end{tabular}

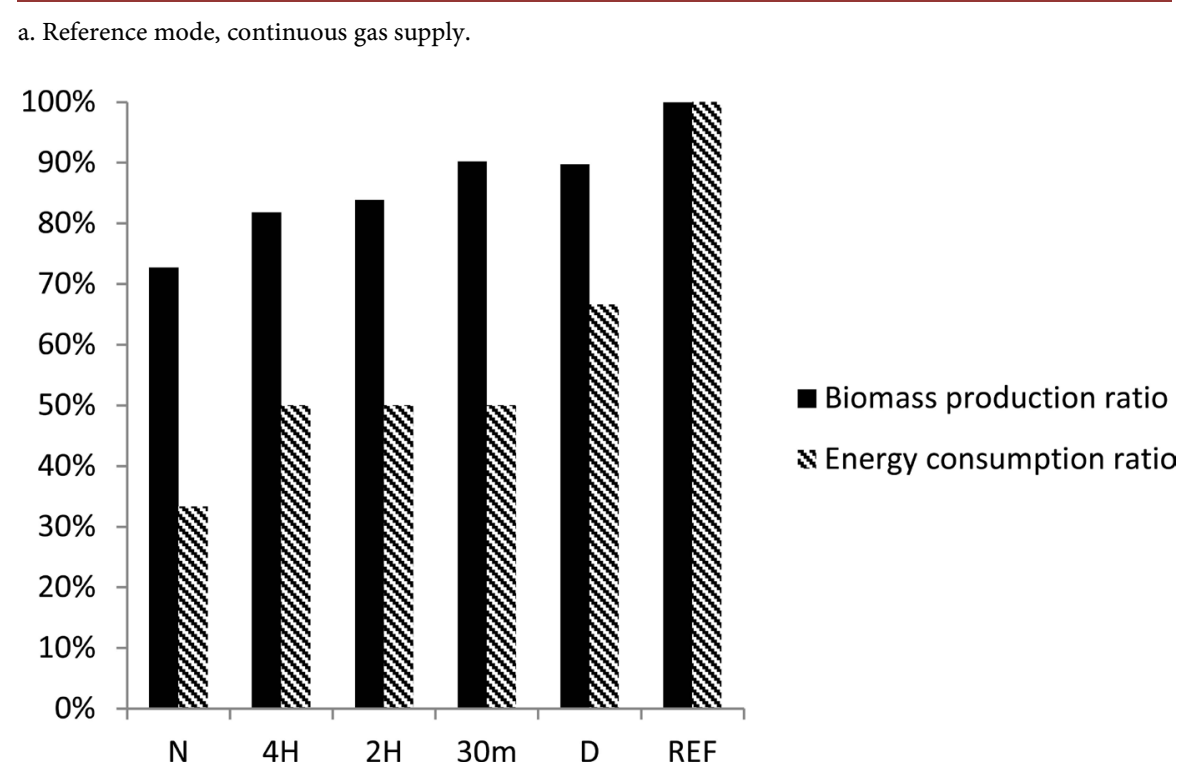

Figure 2. Biomass production and energy consumption at test conditions. 


\section{Conclusions}

We have concluded that energy consumption of gas dispensing in algae cultivation can be lowering to $50 \%$ for the price of $10 \%$ biomass loss.

Considering relative energy consumption and relative biomass production, we can state that $50 \%$ of energy saving can be reached with only $10 \%$ biomass loss by using 30 minutes aeration cycles.

Aeration in only dark phase can be a choice but we should consider its effects on sedimentation, and $30 \%$ biomass loss.

It could be reasonable to investigate how these correlations can be implemented in open pond systems.

\section{References}

[1] BP Statistical Review of World Energy, June 2015, bp.com/statistical review, 2016.02.24.

[2] Ogbonna, J.C. and Tanaka, H. (2000) Light Requirement and Photosynthetic Cell Cultivation: Development of Processes for Efficient Light Utilization in Photobioreactors. Journal of Applied Phycology, 12, 207-218.

[3] Doucha, J., Straka, F. and Livansky, K. (2005) Utilization of Flue Gas for Cultivation of Microalgae (Chlorella sp.) in an Outdoor Open Thin-Layer Photobioreactor. Journal of Applied Phycology, 17, 403-412. https://doi.org/10.1007/s10811-005-8701-7

[4] Van Den Hende, S., Vervaeren, H. and Boon, N. (2012) Flue Gas Compounds and Microalgae: (Bio-)chemical Interactions Leading to Biotechnological Opportunities. Biotechnology Advances, 30, 1405-1424. https://doi.org/10.1016/j.biotechadv.2012.02.015

[5] Kim, J., Lee, J.-Y. and Lu, T. (2014) Effects of Dissolved Inorganic Carbon and Mixing on Autotrophic Growth of Chlorella vulgaris. Biochemical Engineering Journal, 82, 34-40. https://doi.org/10.1016/j.bej.2013.11.007

[6] Raeesossadati, M.J., Ahmadzadeh, H., McHenry, M.P. and Moheimani, N.R. (2014) $\mathrm{CO}_{2}$ Bioremediation by Microalgae in Photobioreactors: Impacts of Biomass and $\mathrm{CO}_{2}$ Concentrations, Light, and Temperature. Algal Research, 6, 78-85.

[7] Blanken, W., Cuaresma, M., Wijffels, R.H. and Janssen, M. (2013) Cultivation of Microalgae on Artificial Light Comes at a Cost. Algal Research, 2, 333-340, https://doi.org/10.1016/j.algal.2013.09.004

[8] Kao, C.-Y., Chiu, S.-Y., Huang, T.-T., Dai, L., Wang, G.-H., Tseng, C.-P., Chen, C.-H. and Lin, C.-S. (2012) A Mutant Strain of Microalga Chlorella sp. for the Carbon Dioxide Capture from Biogas. Biomass and Bioenergy, 36, 132-140. 
Submit or recommend next manuscript to SCIRP and we will provide best service for you:

Accepting pre-submission inquiries through Email, Facebook, LinkedIn, Twitter, etc. A wide selection of journals (inclusive of 9 subjects, more than 200 journals)

Providing 24-hour high-quality service

User-friendly online submission system

Fair and swift peer-review system

Efficient typesetting and proofreading procedure

Display of the result of downloads and visits, as well as the number of cited articles Maximum dissemination of your research work

Submit your manuscript at: http://papersubmission.scirp.org/

Or contact wjet@scirp.org 